\title{
Response of Native White Sorghum to Irrigation under Different Nitrogen-Fertility Levels and Seeding Rates in Lajas Valley, Puerto Ricol
}

\author{
R. Vazquez, A. lischenwald-Hess, and M. J. Martinez-Luciano
}

\section{INTRODUCTION}

Sine sorghum (Sorghnm mulgare Pers.) is quite resistant to drought, it has been grown mostly in areas of limited rainfall. However, sorghum responds well to irrigation and, at present, with the irrigation system established in the Jajas Valley, its culture has been shifted to irrigation agriculture. The native white variety of sorghum is the most extensively planted forage erop for silage in this region. This plant provided the solution for the scareity of fodder during the long drought periods in this arcit.

Although sorghum can be used for grain and forage, it has been used mostly as forage specially for silage. According to Hughes et al. (2) ${ }^{3}$ sorghum silage hat largely replared corn silage in Kansas, Nebraska, Texas, and Oklathoma. $d *$ they reported, the feeding value of silage made from corn and from sorghum is generally considered to be the same.

Sorghum is produced fairly well on all types of soil, growth being dependent upon the relative fertility and soil-moisture supply.

Jimiterl reseirreh lins been done with sorghum in Puerto Rico. It has been observed giving a good response to irrigation and fertilizers. Howcver, there are no available data on the irrigation recturements, seeding rates, and fertilizer needs of this crop.

It may be concluded that our grasslands need better management and improvement practices in order 10 maintain a large livestock industry. Since sorghum is one of the most important forage crops in the area, it is proposed 10 sludy its irrigation requirements and fertilizer needs under different seeding rates in order to obtain optimum yields.

\section{EXPERIMENTAL PROCEOURE}

'The experiment was planted .1 ray 22,1961 , and harvested every 77 days, the last harvest having been made on August 27, 1962. A split-plot design

1 'This research was done as part of a contributing project of the Southern Regional Project $\mathrm{s}-24$.

"Asseciate Irrigation Scientist, Agricultural Engineer, and Professor in charge, and Research Assistant in Agronomy, respectively, Lajas Substation of the Agriculturil Lxperiment Station, University of Puerto Rico, Río Piedras, P.R.

${ }^{3}$ Italic numbers in parentheses refer to Literature Cited, p. 112. 
with whole units in latin sequare and subunits in $3 \times 3$ balaneed lathieces was used. The treatments ineluded a combination of four irrigation treat. ments, three nitrogen levels, and thee seeding rates with four replicutions. A sorghum variety, White Native, was planted with 3 feet between rows and 3 seeding rates. The plots were six rows (18 feel) wide and 18 feet long.

\section{TRRIGATION}

The following irrigation treatmenls were lied:

1. High moisture: Plots irrigated when the average soil moishure surtion in the aclive mot-zone reached $0.7 \mathrm{afm}$.

2. Nedium moisture: Plots irrigated when the average soil moisture: suction in the active root-zone reached $2 \mathrm{~atm}$.

3. Low moisture: Plots irrigated when the average soil-moislure suction in the active root-zone reached at atm.

4. Nonirrigated: Plots were not irrigated aflex the arop was established.

Furrows about 4 inches deep and 3 fect apart were made in the whole experiment for the purpose of irrigation. lieeding ditehes were made at the head of each irrigation block and used as equalizing bays by means of plastic dams placed at the end of each block. Plastic siphon tubes were used as flow controls for each lurrow. A heavy irrigation was aplylied to the whole area after being planted. After cach harvest a luiform irrigation was applied to all the irrigited plots.

\section{PLANT POITILATLON}

The seeding rates tried were 10,20, and 30 pounds of seed per acre. White Native sorghum varjety was sown on top of the beds with a 3-foot distance betwem rows, the amount of seed used depending on the seeding rate. Seedlings wore altacked by blackbirds (Quiscalus niger brachyptemus). Reseedings were done on Jume 5,6 , and 7. The whole exprument was irrigated after being reseeded.

\section{FEIRTLIZER}

Nitrogen fertilizer in the form of ammonium sulfate (20.5-perent $\mathrm{N}$ ) was applied at the rate of 40,80 , and 120 pounds per acre per erop. After each harvest the whole experiment was fertilized according to the (reatments involved. Phosphorus and potassium in the form of superphosphate (20.5-percent $\mathrm{P}_{2} \mathrm{O}_{5}$ ), and muriate of potash (61-percent $\left.\mathrm{K}_{2}()\right)$, respertively, were applied to the whole experiment at the rate of 200 pounds each of $\mathrm{P}_{2} \mathrm{O}_{5}$ and $\mathrm{K}_{2} \mathrm{O}$ per acre per year. All the fertilizer was broadcast along the planter row. 


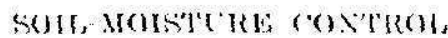

Bulk-densily determinations were made of soil samples taken from is to 6 and 18 to 21 inches depths.

Tensiometers (3) were installed in one of the high-moisture plots under 40 and 120 pounds of nitrogen treatment at 6-, 12-, 18-, and 24-inch depths, respectively. Those plots were inigated when the average soil-moisture suction in the active root-zone becume $700 \mathrm{~cm}$. of water. (rypsum resistance blocks of the Bouyouros type (1) were installed at 6-, 12-, 18-, and 24-inch dephes in one of the medimm-moisture, low-moisture, and nomiriguted plots under 10 and 120 pounds of nitrogen treatment, despeetively. The irrigation of the mediun-moisture and low-moisture plots wore made when the average pristanee readings equalled 2 and 5 atm. of suction, respectively.

About 2 inches of water were applied in each irvigntion (table 1). Snil samples for moisture deternination wero taken during each growing period throughout the course of the experinent to calculate the moisture extracted from the root-zone in earh moisture treatment. Duplicate soil sumples were taken with a srew-lype soil auger at the following depths: 0 to 6,6 to 12 , 12 to 18 , and 18 to 24 inches. The soil samples were taken twiec a week, especially 1 day before and 2 days after each irrigation in the plots receiving 80 and 120 pounds of nitrogen treatment under each itrigation level.

All sumples were weighed :und placed in an oven for 24 hours at $105^{\circ} \mathrm{C}$, and the perentage of moishue was determined on an oven-dry-woight basis. The waler axtracted from the lop 2 feet under ach irigation troument was calculated for a growing period of five consecutive crops. A tolal of four samples under atch moisture treatment at each different depth sumpled was used to ealculate the water extracted during those short periods and throughout the whole growing senson. The consumptive use of water was colculated by adding the offertive rainfalt to the water extrated during those periods.

('VIEURA, PRACTICES

After each harvest the plots were weeded and fertilized arcording to the fertilizer treatmentr. Additional weedings were made as necessary to maintain the plots free of weeds. Insecticides were applied for insect control. Every 77 days the plots were harvested and weighed to determine greenforage production. Samples were taken to determine dry-matier percentage and protein content.

- If the rainfall was greater than 1 inch a day, the efleetive rainfall was assumed to be 66 pereent of the total rainfall for that partieular day. 


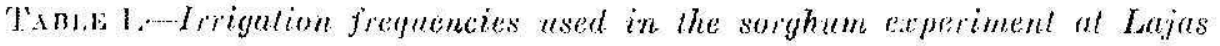
Substation, 1961-6\%

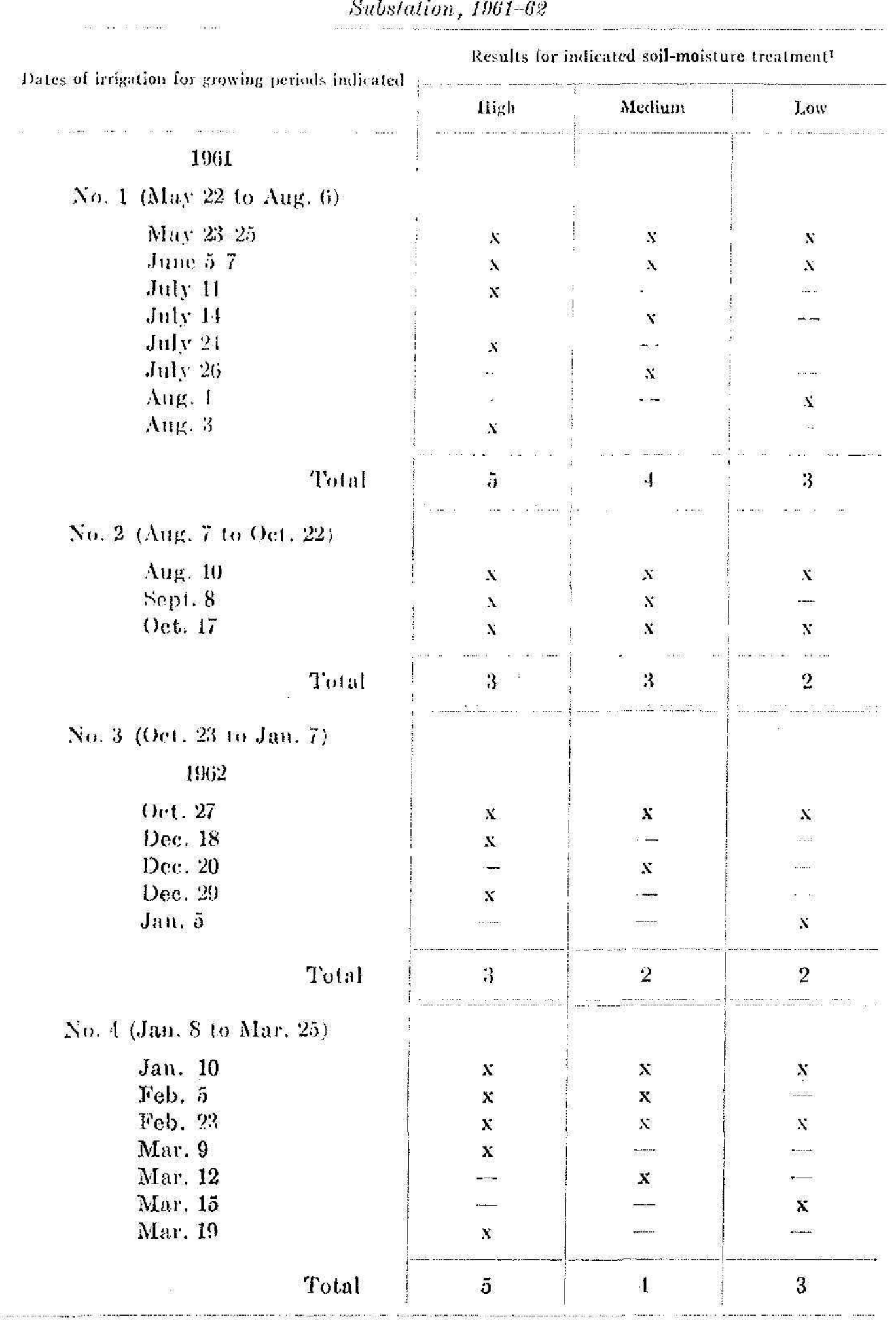




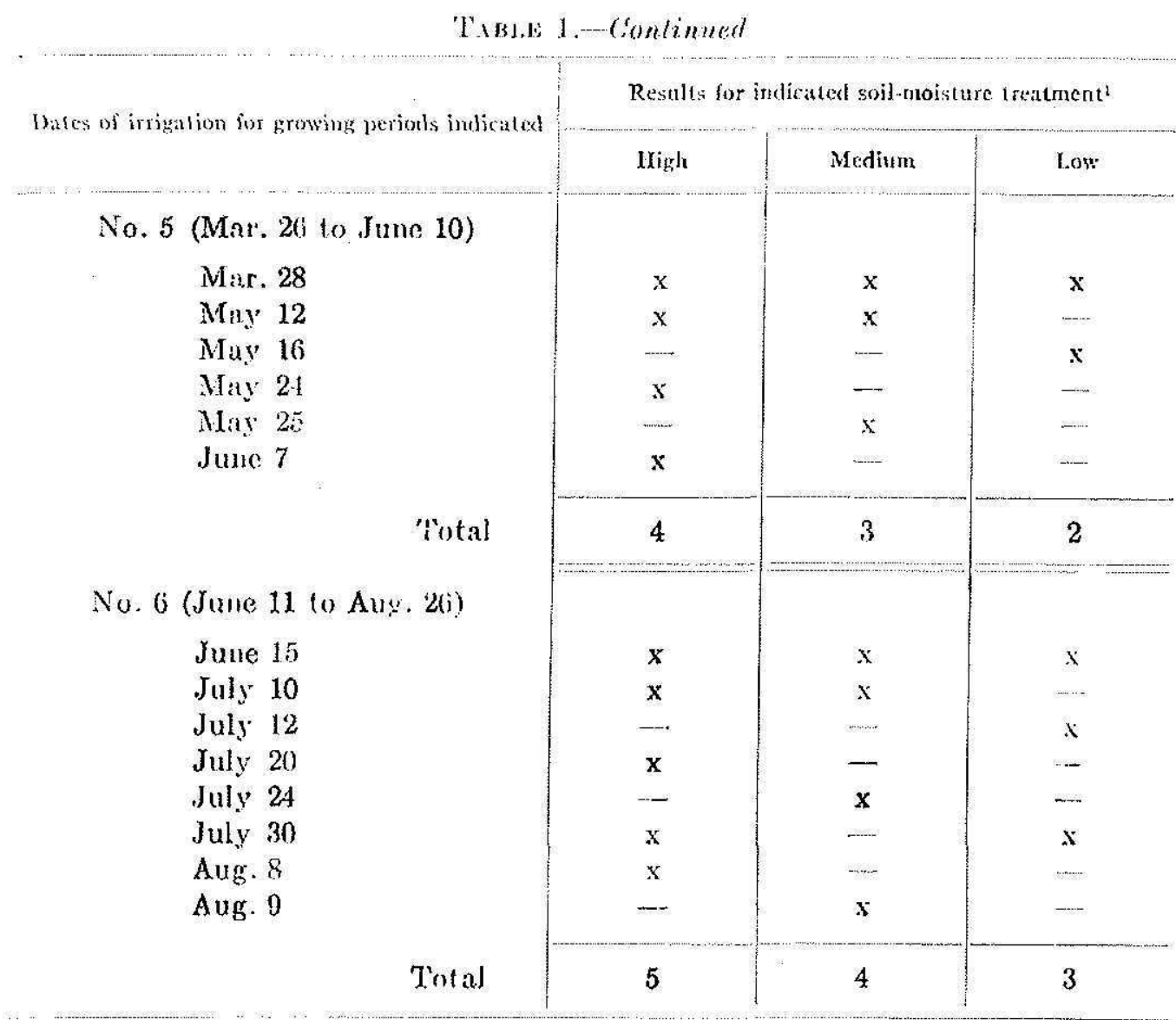

1 The high-moisfure, medium-moisture, and low-moisture plots were irrigated whenever the average soil-moisture suction in the active root-zone reached $0.7,2.0$, and 5.0 atm., respectively.

\section{IXPERIMENTAR, RESULTS}

An evaluation was made of the soil-moisture data and the effects of irrigation, nitrogen fertilization, and plant population on dry-matter yields. The results of the first harvest were not laken into consideration because of blackbird dimage to the socdlings and some difficulties encountered in drying the samples for dry matcer determination. After this harvest the experinent was reseeded.

SOIL MOISTURE

An average bulk density of $1.30 \mathrm{gm}$./c.c. was determined for soil samples taken from 3- to 6 -inch deep and $1.22 \mathrm{gm}$. c.c. for the 18 to 21 -inch samples.

The rainfall distribution by days and months throughout the whole growing season and the 17-year monthly average at Lajas Substation are 
TABLE 2.--Inches of daily rainfall during the growth period of the sorghtm experiment at Lajus, P.R., 1961-6\%

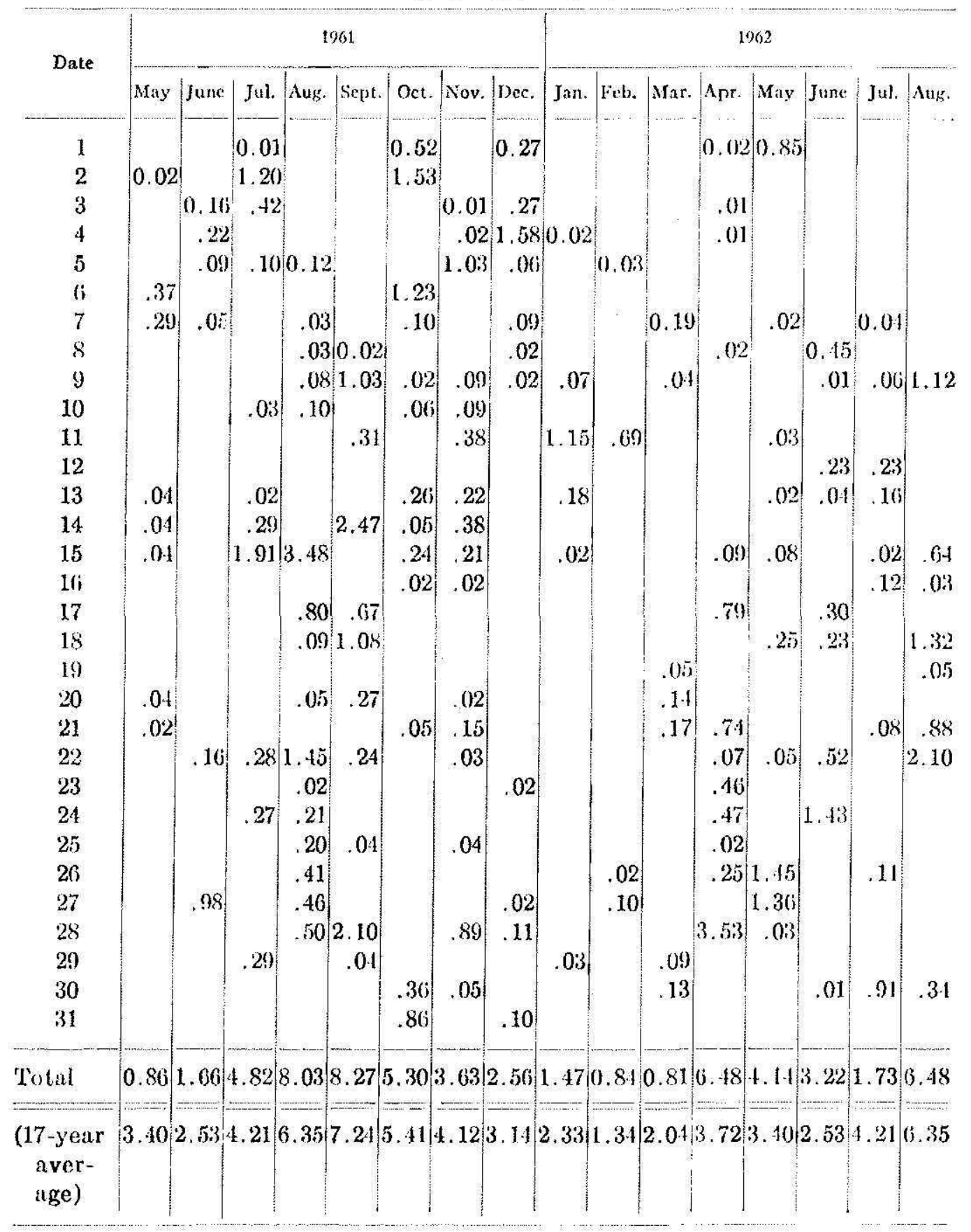

shown in table 2. A close examination of the 17-year monthy average shows that the rainfall during the months of April, May, and Junc of 1962 was higher than the normal ranfall for that period. It also shows that the period of highest rainfall (rainy season) oceurs during the months of July to November. 
The ronsumptive nse of water during short periods of time and throughout the course of the experiment is presented in tables 3 to 6 . These tables show the watcr-used variation within cach growing period. The total and daily average of water used by sorghum during each growing period under different moisture treatments is shown in table 7 and figure 1. This table, as well as figure 1, shows a seasonal effect on water used by sorghum. They also show the variation in water used among the difterent moisture troutments.

The highest average daily water used in the irrigated treatments observed was 0.227 inches during the period of August to Octoher; the lowest was 0.1 .2 inches during the period of tamuary to Marel. The yearly wateruned variation in the high moisture plots was from a daily average of $0.25 t$ inch during the period of dugust 7 to October 22 , to 0.167 inch from 0 (tober 23 to January 7 , to 0.119 inch from January 8 to Narch 25 , to 0.187 inch from March 26 to June 10 , and 0.177 inch from June 11 to August 26. In the medium-moisture plots the average daily water used was 0.230 , $0.137,0.128,0.168$, and 0.151 inch for eanh respective growth period. The low-moisture plots exhibited a variation of $0.197,0.128,0.089,0.167$, and 0.156 inch per day for the respective growth periods. The lotal water used in iuches during the 385-day growing period was $69.57 \mathrm{l}$ in the high-moisture,

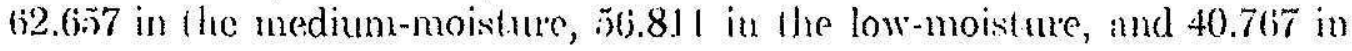
the romingigaled plot:.

\section{MFFECIS OF IRIICATION}

Irrigation effects on yields at difterent levels of fertilizer are presented in table 8. As ean be observed in this table irrigation did not increase yields signifiantly in the first two harvests. However, in the last, three harvests imigation increased lorage yields in a highly significut way. The combincd statistical antlysis of five crops havested shows a highly signifient elfect of ingigation on forage yields. As in the individual analysis, it shows that there were no significant differences in yieds between the high-moisture, medimm-nnoisture, and low-moisture plots. The avorage increase in yields altributed to irrigation was of $2,258,2,031$, and $2,37+$ pounds of dry matter per are in havests 4,5 , and 6, respectively, (derived from table 8). The average increase in total yields during 385 days due to irrigation was of 6,403 pounds of dry mat ter per ane.

\section{LFFECTS OF NITROGEY FERTLLIZA'TION}

Table 8 aks presents the effocts of nitrogen fertilization on forngo yields. This fable and figure 2 , as well as the stalistical analysis of the data, show a highly signifiant quadratic effed of nitrogen concentration upon fornge yiolds. There was a highly signifient increase in yiclds for the 80 -pound- 
Tanus 3.-Consumplive use of water by White Native sorghum in the high-moisture plots, by growing periods, August 7, 1961 to August 86,1962

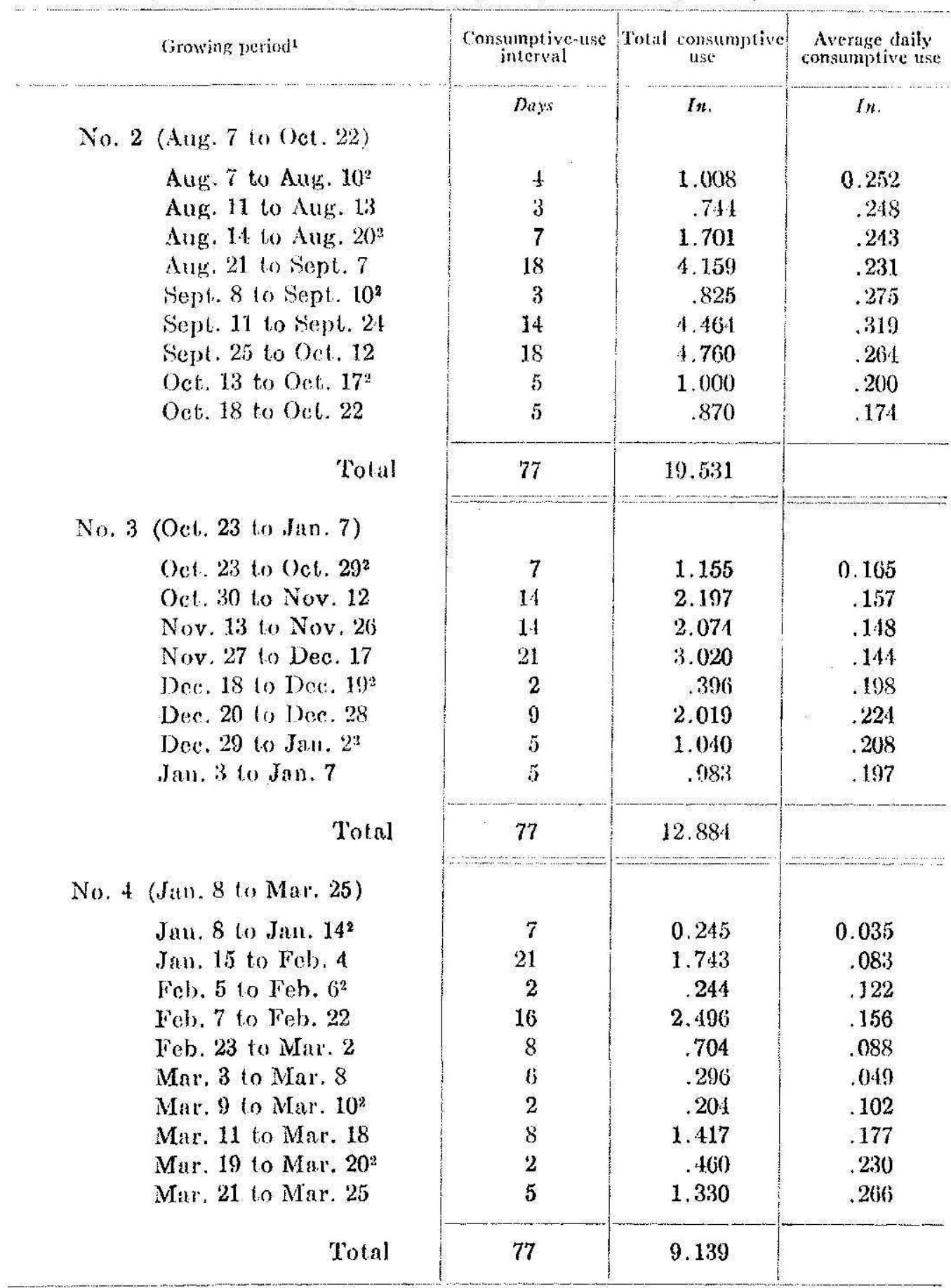




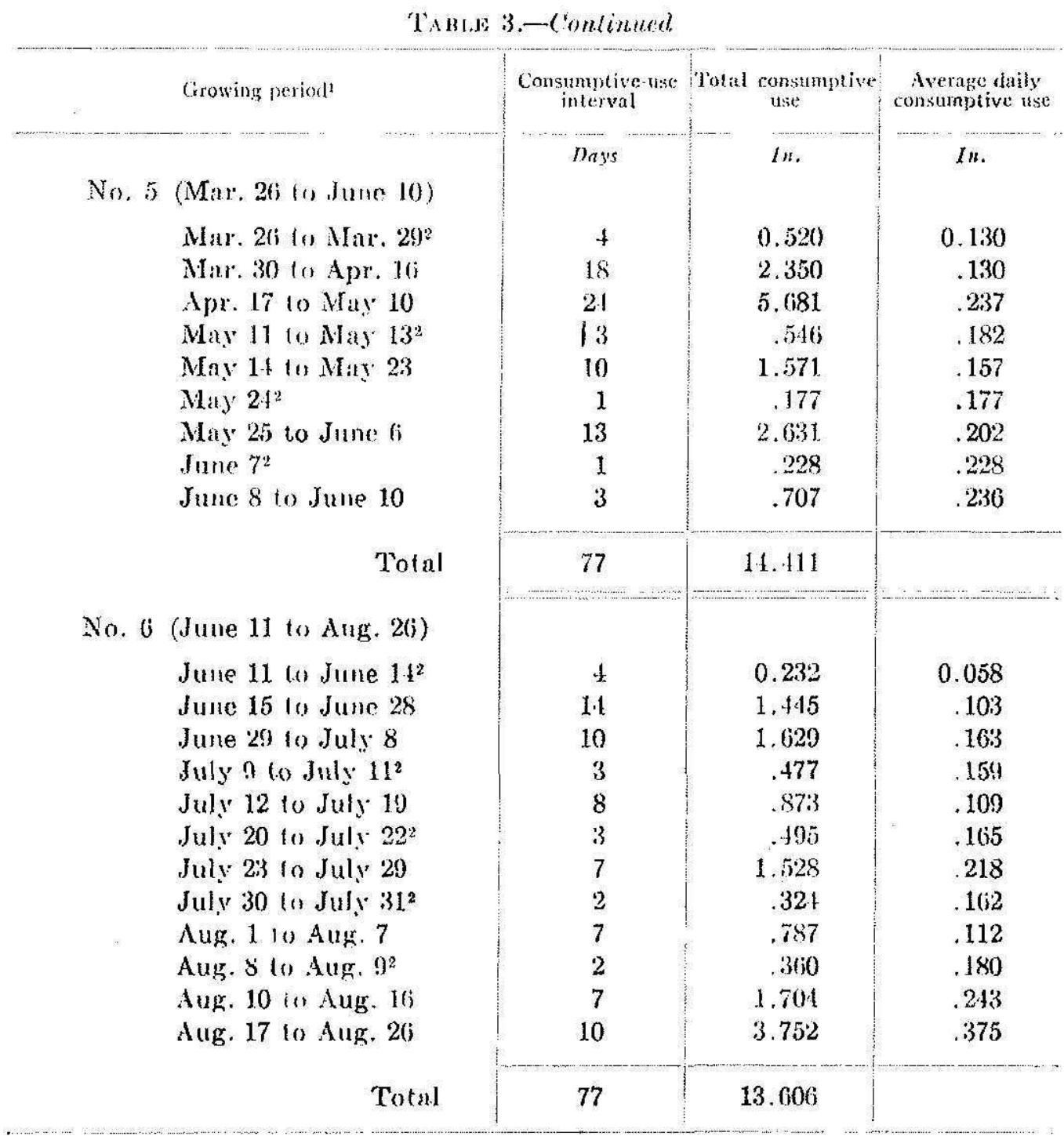

${ }^{1}$ During the first growing period all pots were irrigated as frequently as necessary to establish the crop. The data are not included in this table.

${ }^{2}$ Consumptive-use data calculated by interpolation.

nitrogen trealment over the 40-pound treatment in all harvests; however, the 120-pound-nitrogen urament outyidded the 80-pound in the last three crops only. The combined analysis of five harvests shows a significant quadratic eflect on yields, the 80 -pound outyielding the 40-pound and the 120 -pound outyielding the 80 -pound treatment. The total increase in yields due to an increase in nitrogen fertilizer from 40 to 80 pounds per acre per crop was 8,500 pounds of d'y matter per acre in 385 days, while 40 more pounds over the 80 -pound treatment increased the yields only by 2,561 pounds (derived from table 8 ). 


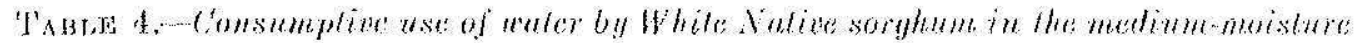

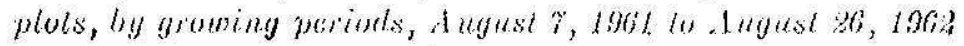

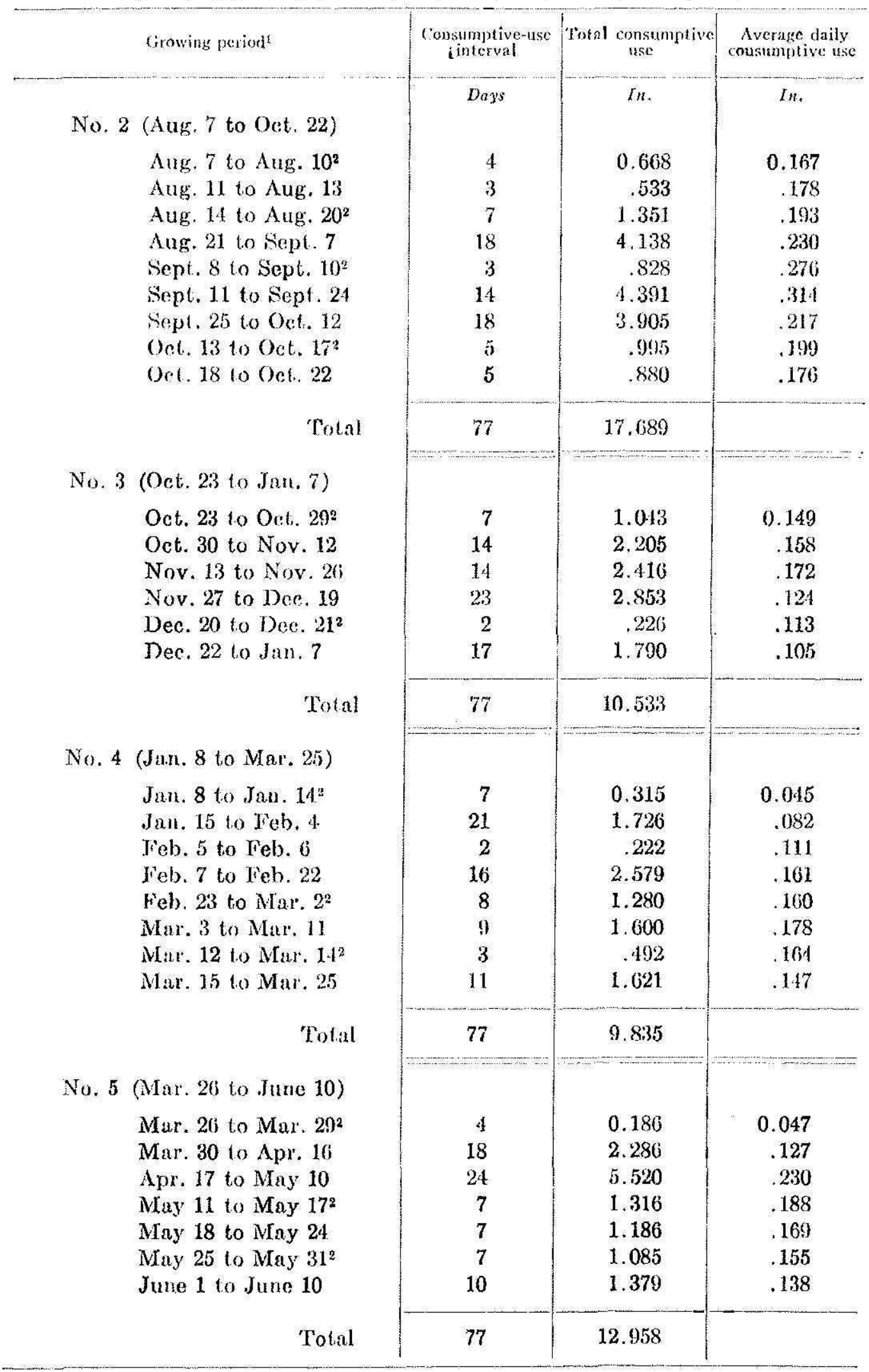




\begin{tabular}{|c|c|c|c|}
\hline Growing period ${ }^{t}$ & $\begin{array}{c}\text { Consumptive-use } \\
\text { interval }\end{array}$ & Total consumptive & $\begin{array}{l}\text { Average daily } \\
\text { consumptive use }\end{array}$ \\
\hline \multicolumn{4}{|l|}{ No. 6 (June 11 to Aug. 26) } \\
\hline June 11 to June $14^{2}$ & 4 & 0.332 & 0.083 \\
\hline Jure 15 to June 28 & 14 & $\quad 1.104$ & .083 \\
\hline June 29 to July 8 & 10 & 2.107 & .211 \\
\hline July 9 to July 11 & 3 & .474 & .158 \\
\hline July 12 to July 23 & 12 & 1.184 & .099 \\
\hline July 24 to July $25^{2}$ & 2 & .328 & .164 \\
\hline July 26 to Aug. 8 & 1.4 & 2.5 .44 & .182 \\
\hline Aug. 9 to Aug. $10^{2}$ & 2 & .410 & .205 \\
\hline Aug. 11 to Aug. 26 & 10 & 4.099 & .250 \\
\hline Total & 77 & 12.642 & \\
\hline
\end{tabular}

1 During the first growing period all plots were irrignted as frecunently as necessary to establish the crop. The data are not included in this table.

${ }^{2}$ Consumplive-use data calculated by interpolation.

There was a significant interaction between irrigation and nitrogen fertilizer in the last (wo crops harvested. The combined analysis of five crops harvested shows a highly significant interaction between irrigation and nitrogen fertilizer applications (see fig. 2).

Nitrogen and irrigation effects on the protein content of the sorghum forage are shown on table 9. As can be observed nitrogen fertilization increased the protein content of the forage while irrigation docreased it. The largest differences were observed between the 40- and 80-pound-nitrogen treatments and between irrigated and nonirrigated trentments. The average protein content of the forage was $4.97,6.18$, and 7.18 perceut for the 40-, 80-, and 120-pound-nitrogen treatments, respectively. In the highmoisture, medium-moisture, low-moisture, and uonirrigated plots the average protein content was $5.72,5.76,6.03$, and 6.92 perent, respectively.

\section{RFFECTS OF PLANT POPULATION}

The effects of different seeding rates per acre on yields ar: shown in table 10. There was no significant differences in yields between the plots planted with 10, 20, and 30 pounds of seeds per acre under different nitrogen levels. At the 120-pound-nitrogen level an increase in seeding rate shows a slight increase in yields, but the differences were not significant. The interaction between nitrogen concentration and amount of seed per nere is nonsignificant also. 


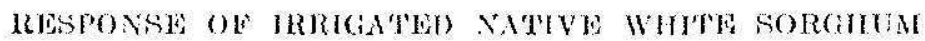

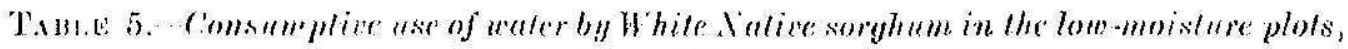
b! growing periods, 1 ugust 7,1901 to $A$ ugust 26,1962

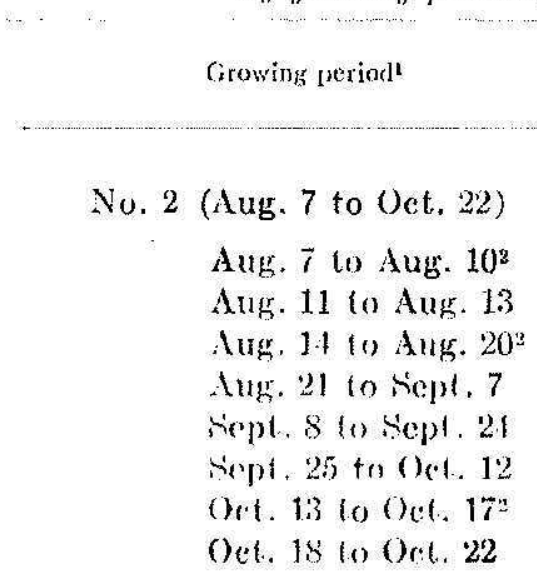

Tolal

No. $3($ (He. .23 (o, Ja11.7)

(). 23 to $0 \mathrm{cl} .29$ ?

(tet. 30 to Nov. 12

Nov. 13 lo Nov. 23

Nuy. 27 to Dor. 17

Dee. 18 10 Jan. I

Jan. 5 fo Jan. $7^{2}$

Iolal

No. 4 (Ja11. 8 to Mar. 25)

Jan. 8 to Jan, $14^{2}$ Jan, 15 to lieb. 4

Fieb. 5 to Feb. 22

Feb. 23 to Mar. $2^{2}$

Mar. 3 to Mar. 14

Mar. $15^{2}$

Mar. 10 to Mar. 25

Iotal

No. 5 (Mar. 20 to Jane 10)

Mar. 26 to Mar. $29^{2}$

Mar. 30 to Apr. 22

Apr. 23 to May 15

May 16 to May $17^{2}$

May 18 to June 10

\begin{tabular}{|c|c|c|}
\hline $\begin{array}{c}\text { Consunptive use } \\
\text { interval }\end{array}$ & $\begin{array}{c}\text { lotil consumptive } \\
\text { use }\end{array}$ & $\begin{array}{l}\text { Average daily } \\
\text { consumptive use }\end{array}$ \\
\hline Dilys & ln. & $I n$. \\
\hline 1 & $0.6 i 30$ & 0.150 \\
\hline 3 & .530 & $.17 \vec{i}$ \\
\hline 7 & $1.30^{\circ}$ & .180 \\
\hline 18 & 1.521 & $\therefore 251$ \\
\hline 17 & 2.117 & .141 \\
\hline 18 & 4.13 .1 & .230 \\
\hline 5 & $.8(6)$ & .172 \\
\hline 5 & .732 & .116 \\
\hline 77 & 15.162 & \\
\hline 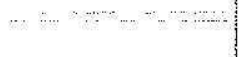 & $=\quad-\quad-1$ & 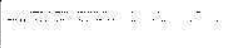 \\
\hline 7 & 1. 042 & $0.15 i$ \\
\hline If & 1.992 & .112 \\
\hline 11 & 1.775 & .127 \\
\hline 21 & 3.773 & .180 \\
\hline 18 & 1.076 & $.0(20)$ \\
\hline 3 & .180 & $.0(1)$ \\
\hline 77 & 9.888 & \\
\hline 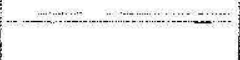 & $\cdots-\cdots$ & $\cdots=\ldots-\cdots$ \\
\hline 7 & 0.175 & 0.025 \\
\hline 21 & .035 & .044 \\
\hline 18 & 1.239 & .069 \\
\hline 8 & 1.048 & .131 \\
\hline 12 & 2.162 & .180 \\
\hline 1 & .145 & .145 \\
\hline 10 & 1.149 & .115 \\
\hline 77 & 6.853 & \\
\hline$(-\infty \cdots+\cdots$ & $\because-\infty-\infty-\infty$ & $\ldots \ldots$ \\
\hline 4 & 0.174 & 0.044 \\
\hline 24 & 2.965 & .124 \\
\hline 23 & 5.498 & .239 \\
\hline 2 & .400 & .200 \\
\hline 24 & 3.835 & .160 \\
\hline 77 & 12.872 & \\
\hline
\end{tabular}




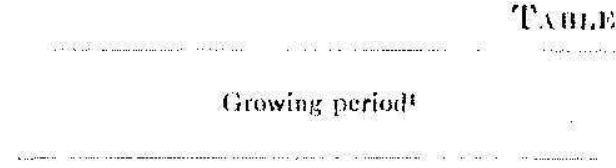

No. 6 (Junc 11 to $A$ ug. 26)

June 11 10, June $14^{2}$

June 15 to June 28

June 29 to July 11

July 12 to July $13^{2}$

July 14 to July 29

July 30 to July $31^{2}$

Aug. 1 lo Aug. 16

Aug. 17 in Aug. 20i

'L'ot:1
Wurl: i).-- Continued

\begin{tabular}{|c|c|c|}
$\begin{array}{c}\text { Consumptive-use } \\
\text { interval }\end{array}$ & $\begin{array}{c}\text { Total consumptive } \\
\text { use }\end{array}$ & $\begin{array}{c}\text { Average daily } \\
\text { consumptive use }\end{array}$ \\
\hline Days & $I n$. & In. \\
& & \\
1 & 0.548 & 0.137 \\
14 & 1.610 & .115 \\
13 & 1.070 & .082 \\
2 & .212 & .121 \\
16 & 2.706 & .169 \\
2 & .298 & .149 \\
16 & 2.080 & .130 \\
10 & 3.476 & .318 \\
77 & 12.036 & \\
\hline 7 & & \\
\hline
\end{tabular}

1 During the first growing period all plots were irrigated as frequently as uecessay to establish the rrop. The dat a are not. included in this table.

"Consumptive-use data calculated by iuterpolation.

\section{DISCUSSION}

As in ouher fornge speries (4), a seasonal effer on the consumplive use of water by White Native sorghum was observed in this experiment (ses fig. 1). As shown in ligure 1. then was a higher water use for the period of August 1961 than for August 1962. This can be explained by the infuence of heavier minfall observed during the period of 1961 (see table 2), or probably by a decrease in growth attributable to cutting effects.

Irrigation did not increase forage yields during the period of August 7 to January 7 . A look at lable 2 shows that this period corresponds to the ruiny season in Lajas Valley. From January 8 to August 26, irrigation increased yields significantly; however, there were no significant differences in yields between the irrigation tratiments. 'The irrigations to the plots with 2 and 5 allar. of suction were made using Cel-WWD Boyoucos gypsum resistance blocks as the index. The calibration of these blocks shows a resishane of 910 and 1950 ohms, equivalent to 2.0 and $5.0 \mathrm{~atm}$., respertively. Fividently these resistance readiugs aro too low for the respective soil-moisture treatments with this type of unit. In other words, tho irrigation treatments were not applied as intended. Although the high-moisture plots received 20 irrigations, the medium-moisture 16 , and the low-moisture 12 ; the difference in moisture was insufficient to affect the sorghum yields significantly.

Since the forage yields were not affected between the irrigation treatments, and during the period of August 7 to January 7 irrigation did not increase yickls significantily, the representative consumplive use of water 
Tance 6.-Consumptive use of water by White Vatine sorghum in the nonirrigated plots, by growing periods, A uyust 7, 1961 to August 26, 1962

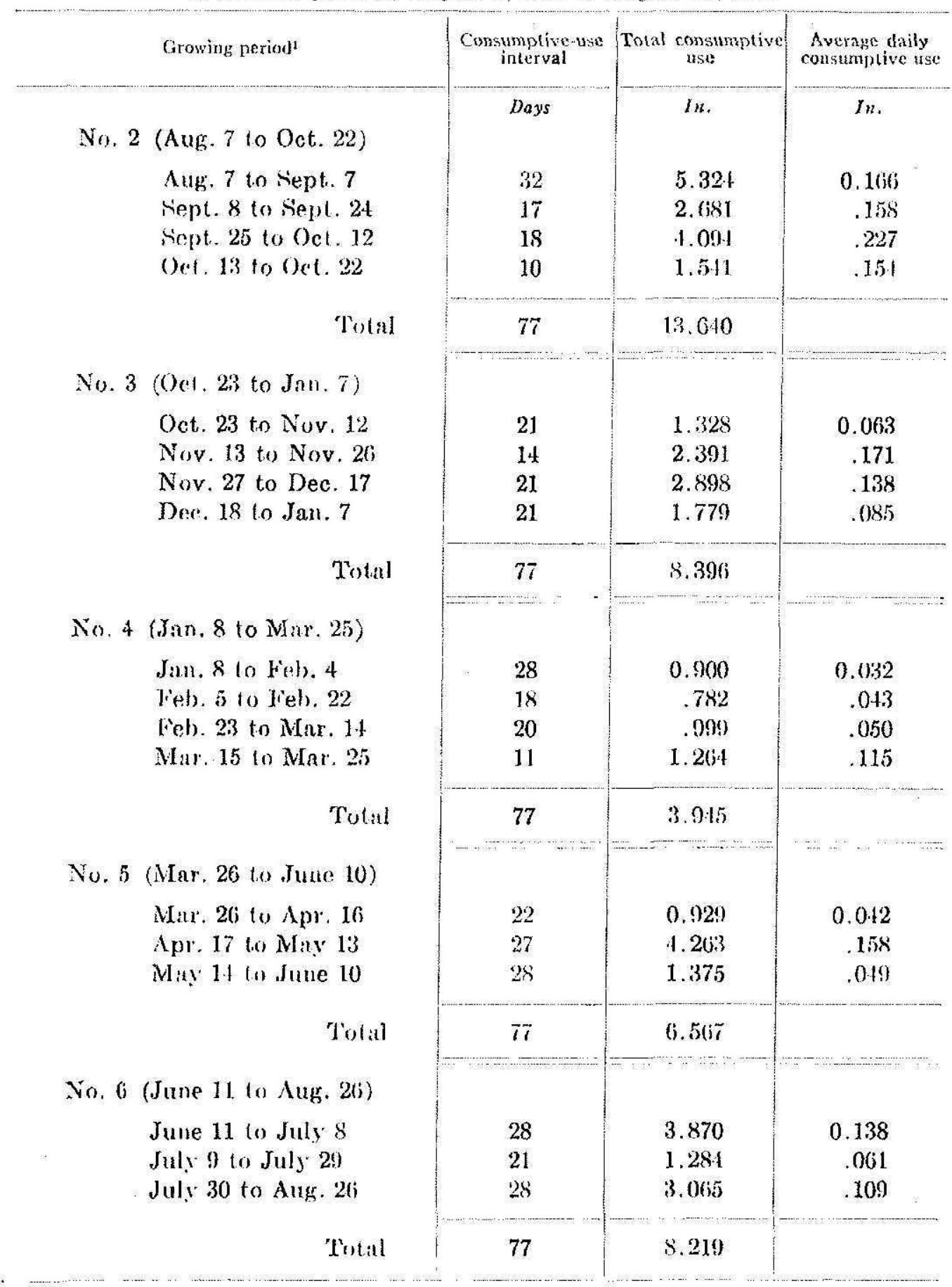

${ }^{1}$ During the fist growing period all plot: wore irrigated as frequently as necessary to establish the crop. The data are not included in this table. 
by White Native sorghum can be assumed to be that of the nonirrigated plots from August 7 to January 7 , and from January 8 to August 26 that of the low-moisture plots (sce table 7). The total consumptive use in 385 days would be 53.797 inches, or an average of 0.110 inch per day, which is lower than the one determined by the author (4) for Guinea grass and Para grass in the sume area. 'This probably can be explained by the limited 2 foot depth of sampling to calculate the moisture extracted from the rootzone, by the low-moisture treatmont which was the representalive one in

\begin{tabular}{|c|c|c|c|c|c|c|c|c|c|}
\hline \multirow{3}{*}{ Growing period' } & \multicolumn{8}{|c|}{$\begin{array}{c}\text { Consumptive use (in incles) under inclicated } \\
\text { irrigation treatment }\end{array}$} & \multirow{3}{*}{$\begin{array}{l}\text { Average } \\
\text { daily } \\
\text { con- } \\
\text { sump- } \\
\text { tive } \\
\text { use in } \\
\text { inches? }\end{array}$} \\
\hline & \multicolumn{2}{|c|}{ High moisture } & \multicolumn{2}{|c|}{$\begin{array}{l}\text { Merlium } \\
\text { moisture }\end{array}$} & \multicolumn{2}{|c|}{ Low moisture } & \multicolumn{2}{|c|}{ Nonirrigated } & \\
\hline & Total & $\begin{array}{l}\text { Daily } \\
\text { ave. }\end{array}$ & 'Total & $\begin{array}{l}\text { Daily } \\
\text { ave. }\end{array}$ & Total & $\begin{array}{c}\text { I iaily } \\
\text { ave. }\end{array}$ & Total & $\begin{array}{l}\text { Ditily } \\
\text { ave. }\end{array}$ & \\
\hline $\mathrm{No.} 2$ (Aug. 7 to Oct. 22) & 19.531 & 0.251 & 17.680 & 0.230 & 15.102 & 0.197 & 13.61010 & 0.177 & 0.227 \\
\hline No. 3 (()ct. 23 to Jan. 7$)$ & 12.884 & .167 & 10.5333 & .137 & 9.888 & .128 & 8.306 & .100 & .14 \\
\hline No.t (Jan. 8 to Mar. 25) & 9.139 & .119 & 9.835 & .128 & $(i .853$ & .089 & 3.945 & .051 & .112 \\
\hline No. 5 (Mar. 26 to June 10) & $1+.111$ & .187 & 12.958 & .168 & 12.872 & .167 & 6.567 & .085 & .174 \\
\hline No. 6 (June, 11 lu Aug. 2(i) & 13.606 & .177 & 11.6 .12 & .151 & 12.036 & .156 & 8.219 & .107 & .161 \\
\hline Tint:at & 69.571 & & 62,657 & & 50.811 & & $t 0.767$ & & \\
\hline Average por elay & 0.181 & & $0.113 i 3$ & & 0.148 & & 0.106 & & \\
\hline
\end{tabular}

1 During the first growing poriod all plots were irriguted as lreguently as necessary to establish the crop. The data were not ineluded in this tables.

"The nonirrigated plots were not included in this average.

respect to water used in the dry season, or by the plant itwelf which shows a fast recovery after being irrigated.

Table 8 shows that the lowest avorage yield per havest was during harvest No. 6, which is rlose to the avelage obtained during No. 4. Since, acrording to data with other forage grasses reported by the author (1), the lowest yields maty be expecoled during the winter months, it serms likely that the reduction in yichs during harvest No. 6, may have bern caused by rulling offects of the original sorghum plants.

Nitrogen increased yields significantly; however, it. had a significint quadratic effect on yieds (see lable 8 and fig. 2). In of her works, the first $t 0$ pounds of nitrogen over the initial fertilizer treatment had a linear relation of yicld increase with respect to nitrogen-fertilizer ardditions; how- 
ever, with the next 40 pounds of extra nitrogen the eurve tended to level off. $A$ look at able 8 shows that forage yields were incroased by the 120 pound nitrogen treatment in harvests 4,5 , and 6 . This ovidently shows that a better use of the fertilizer is male during spring and summer.

Seeding rates over 10 pounds per acre did not increase forage yiolds signifienully. But, as shown in tuble 10, there was a tendeney to increase

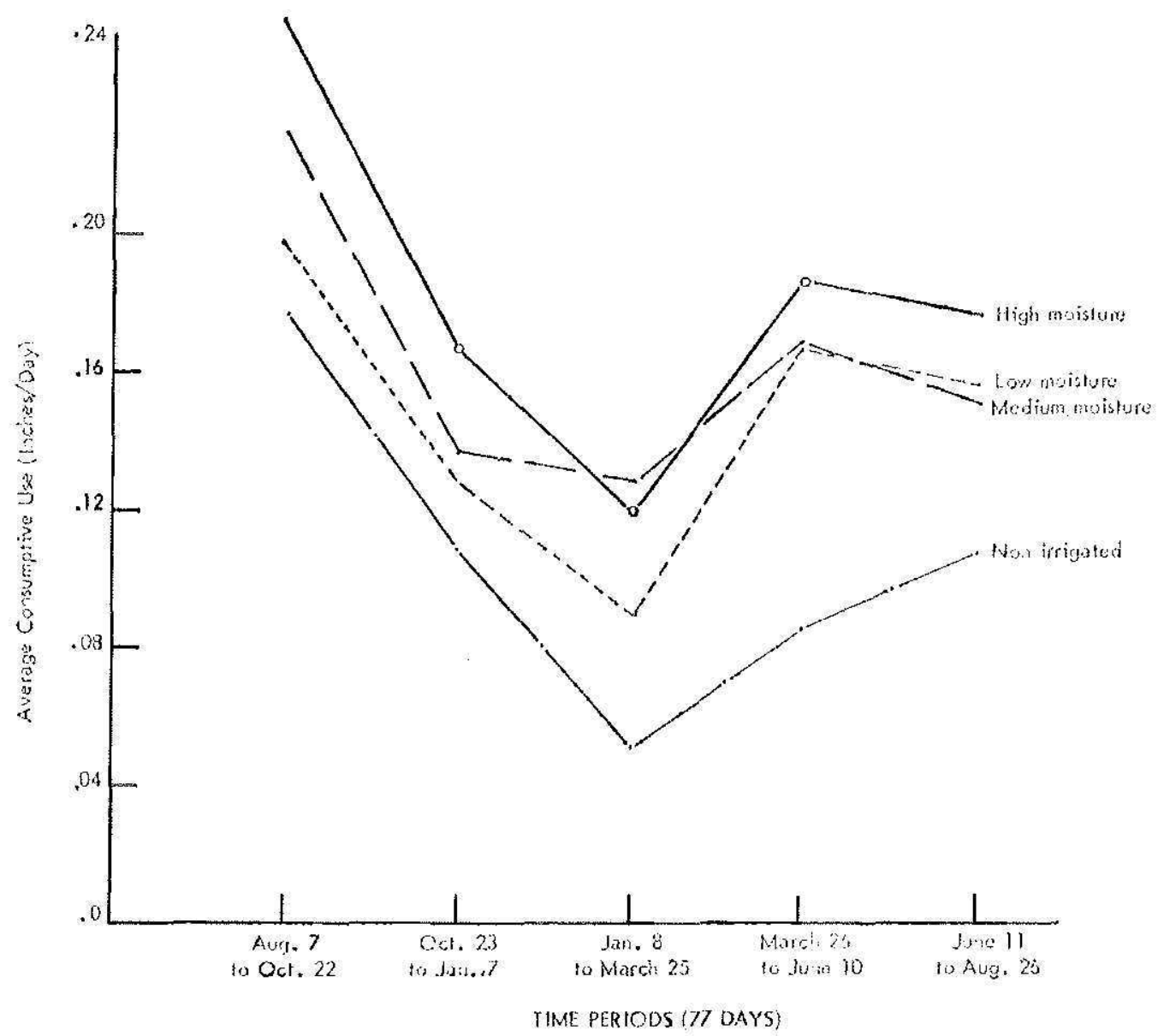

Fir. 1.-. Sensonal eflects on the consumplive nse of water by White Native sorghum at Lajas Substation, 1961-62.

forage production with an increase in seeding lates al the 120-pound-nitrogen level. This suggests that the limiting factor on the respouse to higher sceding rates is the nitrogen fertility level.

In general, we can conclude that irrigation and nitrogen fertilizer applications, without high seeding rates, are necessary to obtain maximum yields of sorghum forage in Lajas Valley. Further recearch is necessary on the soilmoisture aspect, especially within the rnnge of 5 to 15 atm., although it would be helpful to check the calibration of the gypsum resistance blocks and start; with 2 atm. again. 
T.1kr.: 8.- Elpects of irrigation and nitrogen ferlilization on the yields (pounds of diz maller per acre) of White Natine sorghum at different periods of time from

August 7, 1961 to August 20, $196 \%$

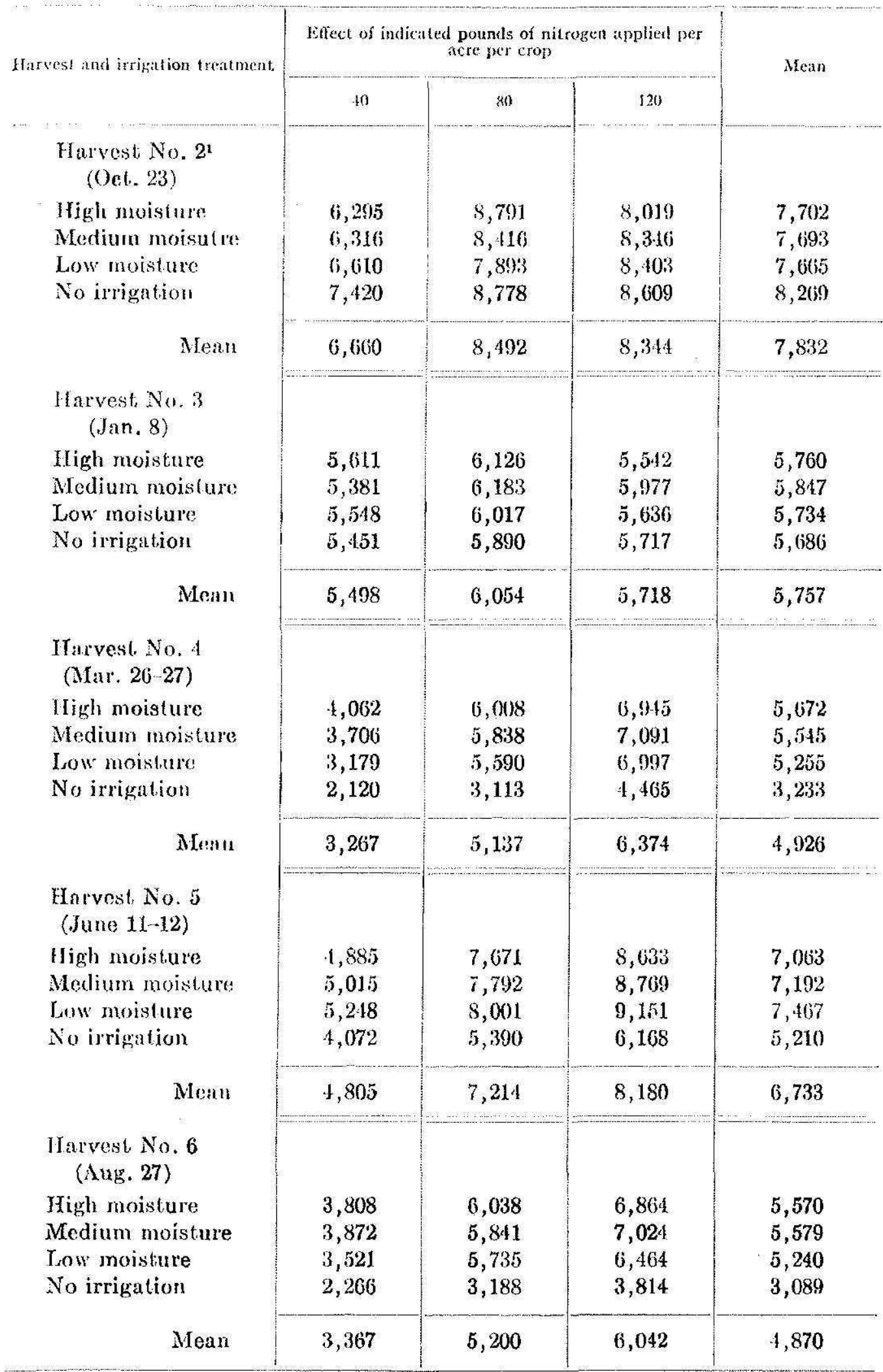

${ }_{1}$ Results of the first harvest were not taken into consideration because of blackbird damage to the seedlings and difficulties encountered in drying the samples taken for dry-matter determination. 


\section{SIMMAIYY}

A field experineut, was conducted at Lajas Substation in order to sudy the effects of four irrigation and three nitrogen levels under three different seeding rates on dry-matter yields of White Native sorghum. The following irrigation treatments were tried:

High moisture, plots irrigated when the average soil-moisture suction in the active root-zone reached $0.7 \mathrm{~atm}$; medium moisture, irrigated when

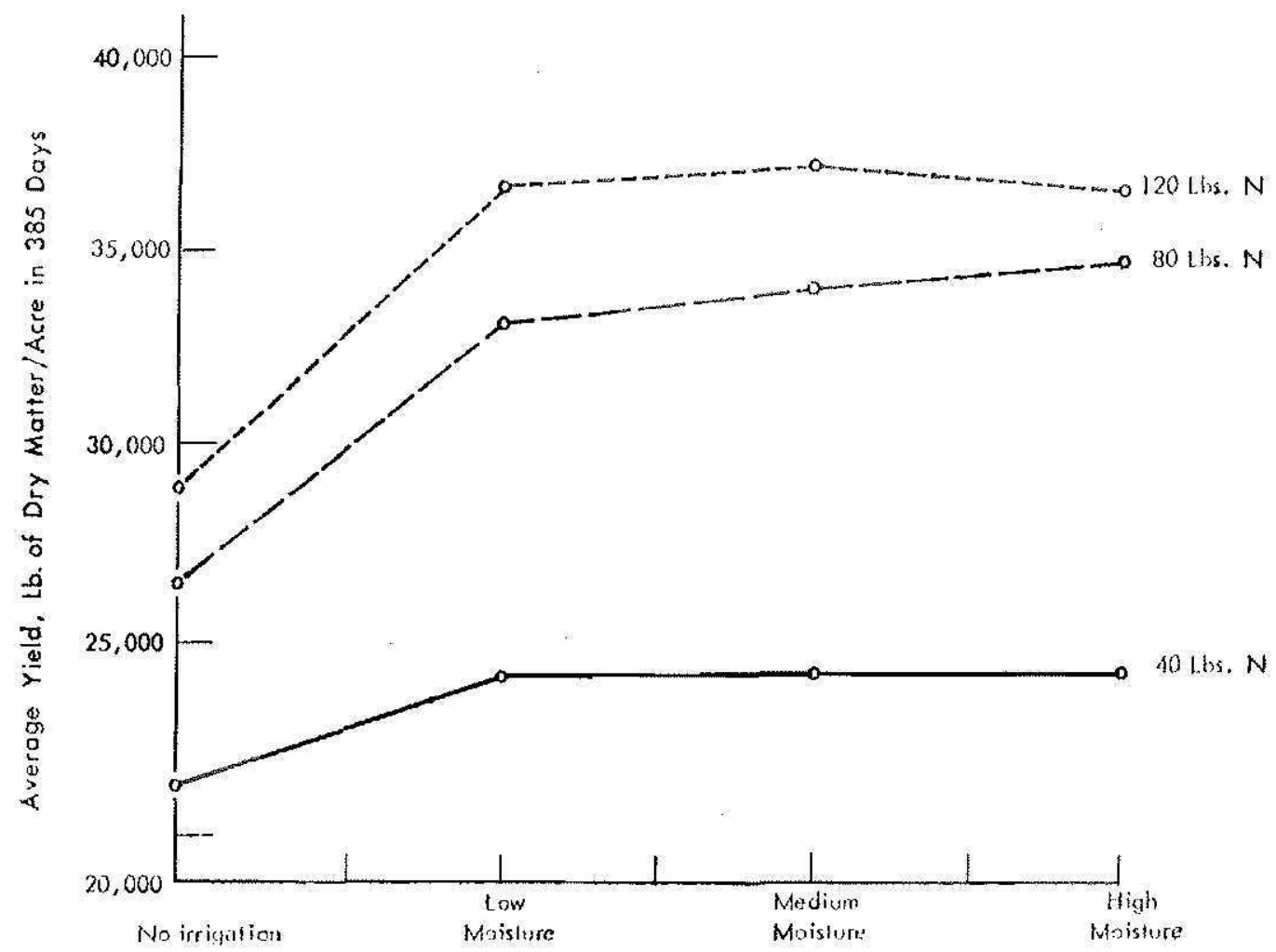

Fiti, 2,- Ettects of irrigation and nitrogen fertilizer applied on dry-matter yields of White Native sorghum al. Jat t: St Substation, 1961 62.

the average soil-moisture suction reached $2.0 \mathrm{~atm}$; low moisture, irrigated when the average soil-moisture suction reached $5.0 \mathrm{~atm}$, and nonirrigated plots were used as check. The nitrogen levels tested were 40,80 , and 120 pounds per acre per harvest. The seeding rates used were 10, 20, and 30 pounds per acre.

In general the results show that:

1. Irrigation increased forage yields significantly during the period of January to August. No response to irrigation was observed from September to December. The average increase in yields during 385 days attributable to irrigation was 6,403 pounds of dry matter per acre. 
2. There was no signifieut difference in production between high-moisture, melimm-moisture, and low-moisture plots. However, the calibration of the gypsum resistance blocks used as an index of invigation show low

TAxLE 9.-Average protein eontent (percent) of While Native sorghum forage al diflerent irrigation and nitrogen levels

\begin{tabular}{|c|c|c|c|c|}
\hline \multirow{2}{*}{ Irrigation treatment } & \multicolumn{3}{|c|}{$\begin{array}{c}\text { Fffects of indicated pounds of nitrogen applied } \\
\text { per acre per crop on the protein content of } \\
\text { sorghtum forage }\end{array}$} & \multirow{2}{*}{ Mean } \\
\hline & $40 \mathrm{~N}$ & $80 \mathrm{~N}$ & $120 \mathrm{~N}$ & \\
\hline High moisture? & 1. (ii) & 5.61 & 6.91 & 5.72 \\
\hline Medium moisilure & 4.74 & 5.96 & 6.59 & 5.76 \\
\hline Tow moisture & 1.85 & 6.13 & 7.11 & 6.03 \\
\hline No irrigation & 5,64 & 7.03 & 8.10 & 6.92 \\
\hline Mean & 4.97 & 6.18 & 7.18 & 6.11 \\
\hline
\end{tabular}

'Average protein content of samples taken in 5 conseeutive crops.

TABCE 10.-E,flect of irrigation, nitrogen ferlitization, and plant population on the total yields (pounds of dry matter per acre) of White Native sorghum forage in 5 consecutive crops

\begin{tabular}{|c|c|c|c|c|c|c|c|c|c|c|}
\hline \multirow{3}{*}{ Irrigation treatment } & \multicolumn{9}{|c|}{$\begin{array}{c}\text { Effect of quantity of seed planted per acre under indicated nitrogen levels, } \\
\text { pounds per acre per crop }\end{array}$} & \multirow{3}{*}{ Menn } \\
\hline & \multicolumn{3}{|c|}{$40 N$} & \multicolumn{3}{|c|}{$80 \mathrm{~N}$} & \multicolumn{3}{|c|}{$120 \mathrm{~N}$} & \\
\hline & $\begin{array}{l}10 \mathrm{lb} \text {. } \\
\text { seed }\end{array}$ & $\begin{array}{l}20 \mathrm{lb} . \\
\text { seed }\end{array}$ & $\begin{array}{l}30 \mathrm{lb} . \\
\text { seed }\end{array}$ & $\begin{array}{l}10 \mathrm{lb} \text {. } \\
\text { seed }\end{array}$ & $\begin{array}{l}20 \mathrm{lb} \text {. } \\
\text { sced }\end{array}$ & $\begin{array}{l}30 \mathrm{lb} . \\
\text { seed }\end{array}$ & $\begin{array}{l}\text { 10 lb. } \\
\text { seed }\end{array}$ & $\begin{array}{l}20 \mathrm{lb} \text {. } \\
\text { seed }\end{array}$ & $\begin{array}{l}30 \mathrm{lb} . \\
\text { seed }\end{array}$ & \\
\hline ITigh moisture & 24,932 & 24,487 & 24,563 & 34,712 & $|34,606|$ & 33,372 & 35,197 & 35,043 & $336,890)$ & 31,6333 \\
\hline $\begin{array}{l}\text { Medium mois- } \\
\text { fure }\end{array}$ & 23,480 & 24,170 & 25,204 & 31,400 & 33,584 & 34,228 & $36 ;, 941$ & 36,124 & $\mid 38,551$ & 31,855 \\
\hline Jow muisturn & 25,495 & 23,740 & 23,051 & 33,472 & 35,147 & 30,304 & 35,447 & 37,304 & $|37,192|$ & 31,270 \\
\hline No irrigation & 21,206 & 21,856 & 20,872 & 26,777 & 26,221 & 25,773 & 20,6335 & 28,904 & $\mid 28,374$ & 25,180 \\
\hline Mean & 23,796 & 23,563 & 23,430 & $32,3 \cdot 10$ & 32,464 & 30,919 & 33,552 & $34, \pi(69)$ & 35,255 & 29,988 \\
\hline
\end{tabular}

resistance readings as equivalent to 2 and 5 atm. Therefore, the irrigation treatments were not accomplished as intended.

3. The representative consumptive use of water in inches by White Native sorghum was as follows: 13.640 from August 7 to October $22 ; 8.396$ from October 23 to January $7 ; 6.853$ from January 8 to March $25 ; 12.872$ from Mareh 26 to June 10; and 12.036 from June 11 to August 26, with a total of 53.797 inches in 385 days.

4. There was a seasonal effect on the consumptive use of water, the high- 
est averige water used, 0.227 inch per day, being observol from August 7 to ()etober 22 , and the lowest, 0.112 inch per day, from fanuary 8 to Mareh 25 .

5. Nitrogen fertilization hat a highly significant quadratic effect on torage yields. The 80-pound-nitrogen treatment outyielded the 40-pound treatment in a highly significant way in all harvests made; however, the auve of forage yields versus nitrogen application tended to level off with 120-pound-nitrogen treatment. The 120-pound-nitrogen treatment outyielded the 80-pound treatment in the last three harvests only.

6. There was a significant interaction between irrigation and nitrogon fertilizer in the last, two crops. The combined analysis of five crops harvested shows a highly significtnt interaction between irrigation and nitorgen fortilizer.

7. Secding mates over 10 pounds per acre did not increase forage yields significantly.

8. Nitrogen fertilizer applications increased the protein coulent of the forage while irrigation denreased it.

\section{RWSUNLY}

En la Subeshación de lajas se llevó a cabo un experimento de campo para estudiar el cfecto de cuatro distintos nieveles de riego, tres de nitrógeno y fres distiutas cantidades de semilla por acre, sobre la produeción de materia seca del millo Blanco del País. Los tratamientos con riego fueron como sigue: Se mantuvo un alto contenido de humedad en ciertas parcelas, aplicándose les riego euando el promedio de succión (tensión) en el área alrededor de las ráces alcanzaba 0.7 de atmósfera; un contenido mediano de humedad cuando el promedio de succión fue de 2.0 atmósferas y un bajo contenido de humedad euando el promedio de succión fue de 5.0 atmósferas. Ias parcolas sin riego sirvieron de testigo. Ios niveles de nitrógeno fueron 40, 80 y 120 libras por acre, por corte. Se usaron 10, 20 y 30 libres de semilla por acre.

En términos gonerales, los datos obtenidos demostraron lo siguiente:

1. Tá aplicación de riego aumentó la producción de forraje durante los meses de encro a agosto, pero el aumento no fue significativo durante el período de septiembre a diciembre.

2. No hubo diferencia significativa entre la producción de las parcelas que recibieron riego. Sin cmbargo, la aplicución de riego no se hizo según indicaban los tratamientos, ya que los bloques de resistencia que se usmon como índice de riego no se calibraron debidamente.

3. El nillo Blanco País requirió las siguientes cantidades de agua: 13.640 pulgadas de agosto 7 a octubre $22 ; 8.396$ de octubre 23 a enero $7 ; 6.853$ 
de enero 8 a marzo $25 ; 12.872$ de maryo 26 a junio 10 y 12.036 de junio 11 it agosto 26 , o sea, un total de 53.797 pulgadas durante 385 días.

1. Lá cilación del año tuvo que ver con el consumo de agua. El mayor consumo, o sea, un promedio de 0.227 de pulgada por día, tuvo lugar de agosto 7 a oulubre 22 , y el más bajo, o sca, 0.112 de pulgada, de enero 8 a marzo 25.

5. La aplicación de nitrógeno tuvo un electo cuadrático altamente significativo sobre la producción de forraje. Es decir, la aplicación de 80 libras de nitrógeno por acre, por cosecha, aumentó la producrión al compararse con el tratamiento de 10 libras, en una forma altamenle significafiva on todas las cosechas. Sin cmbargo, al aplicame 120 libas al anmento en producción fue reduciéndose en comparación con el tratamiento de 80 libras. La aumento en produceión fue significativo solamente en las últimas loes cosechas.

6. Thubo una intexaceión signifieativa contre las aplieacioues do nitógono y riego durante las últimas dos cosechas, mientras que danálisis rombinado de las cinco cosechas roveló que la interneción fuc altamente significativa.

7. Cuatudo se rembraron más de 10 libras de semilla por arere, el aumento on la produsción no fue significativo.

8. La aplicación de nitrógeno numentó el conienido de proténa en el formje, micntras que el riego lo disminuyó.

\section{HTLKATURE CITED}

1. Bonyouess, G. J, New type of electrode for plaster of paris moisture blocks, Soil Sei, 78: 339 42, 195il.

2. Hughes, H. D., Heath, M. E., and Metcalfe, D. S., Forages, Iowa State College Press, Ames, Iowa, 1951.

3. Richards, L. A., Methods of mentsuring soil-moislure tension, Soil Sci. 68: 95-112, 1949 .

4. Varquez, R., Effects of irrigation and nitrogen levels on the yields of Guinea grass, Para grass, and Guinci grass-kudzu, and Para grass-kudzu mixtures in Lajas Valley, J. Agr. Univ. P. R. 49(4): 389-412, 1965. 